\title{
THE PREPOSITIONAL ERRORS IN STUDENTS' WRITING
}

\author{
${ }^{\# 1}$ Riya Risqi Setyaningrum, ${ }^{* 2}$ Riryn Fatmawaty
}

${ }^{\# 1}$ English Education Department, Universitas Islam Lamongan, Indonesia

${ }^{* 2}$ English Education Department, Universitas Islam Lamongan, Indonesia

Corresponding Author Email: riyarisqi@unisla.ac.id

\begin{abstract}
A B S T R A C T S
One of the important things in writing is grammar. The grammatical errors in writing may or will distort and disturb the coherence of the piece of writing. A preposition is a part of grammar that important to connect one word to another. Some students ignore the preposition in the right way. So, this study is eager to analyze the errors in using preposition produced by the students' first semester of English Education Department at Unisla in academic years 2019/2020 that consist of 45 students. The study focuses on what kinds of prepositional errors that are usually produced and the types of errors in using preposition mostly produced. This study uses descriptive qualitative to describes the reasons for preposition errors occur by analyzing the students' writing. The result is the students' first semester still produces some errors in; omission, addition, misformation, and misordering. The types of error that produced by the students is misformation errors with percentage $44,93 \%$. It means the teachers have to pay more attention to teaching prepositions.
\end{abstract}

\begin{tabular}{l}
\hline \multicolumn{1}{c}{ A R T I C L E I N F O } \\
\hline Article History: \\
Received: May, 2020 \\
Revised: June, 2020 \\
Published: June, 2020 \\
\hline Keywords: \\
Writing, \\
Preposition Errors,
\end{tabular}

How to cite: Setyaningrum, R., \& Fatmawaty, R. (2020). The Prepositional Errors in Students' Writing. JoELT (Journal of English Language Teaching) Fakultas Pendidikan Bahasa \& Seni Prodi Pendidikan Bahasa Inggris IKIP, 7(1), 41-50. doi:https://doi.org/10.33394/jo-elt.v7i1.2627

\section{INTRODUCTION}

Language is a social aspect for human life, a form of behavior, and a fundamental part of human life in society. Language has an urgent part in human life because it is a means of communication. Communication uses by all people to interact to other people. By using language, people are able to express their feelings, thought, opinions, and ideas. A language is a tool for expressing ideas or relating information and messages to other people (Brown, 2007). In communicating with others, people have to use language properly and correctly to convey their intentions without any mistakes. One of language that uses to communicate in the world is English.

English is an international language that uses by all people in the world. In Indonesia, English is a foreign language that has to learn and used. Indonesian people have to master their language to face the globalization era where it has implications in politics, economy, culture, and education. In education, all of the students have to master four skills; speaking, writing, reading, and listening. Both speaking and writing are productive skills. The students have to master it more to communicate with other people in the world. Moreover, students need to master vocabulary and grammar.

Grammatical aspects that have to master are verbs, nouns, adjectives, articles, gerunds, preposition, and others. Conducting English grammar is not as easy as master vocabularies. 
Both of speaking and writing, we have to use correct words or structure. It becomes a difficult problem faced by Indonesian students in learning English. Almost all students use Indonesian grammar in their speaking and writing, so the sentences or utterances are errors. Some of the previous studies discussed that the problems of speaking and writing that use by Indonesian students is a grammatical error. The factors in grammatical error are the students have been influenced by the intervention of the first language (mother tongue or Indonesian language) (Suzanne, 2017), the Indonesian students make some errors due to transfer the first language (Napitupulu, 2017), and the students were still confused in selecting the right prepositions (Anjayani, Suprapto, \& Hum, 2016). Especially in English writing, the students used some errors in preposition.

There are some studies about analyzing the students' error in writing. Anjayani and Hum (2016) in their research explain that based on analyzing 72 students' writing, they found 1002 prepositions, $11.68 \%$ of students were incorrect in writing preposition, $66.67 \%$ were error on the use of preposition of place, and $21.65 \%$ were error due to interlingua transfer.

Another research was done by Napitupulu (2017) about analyzing linguistic errors in writing an English letter found that $42.4 \%$ were error in grammatical, $26.7 \%$ of syntactic error, $17.9 \%$ of substance errors, and $13 \%$ of lexical errors. This research has similarities with the research before who done by Anjayani and Hum (2016) who state that students' error in writing due to the first language transfer or use the mother tongue to write in English.

Considering the problem above, grammar is one of the important things that have to master by all of the students especially in Indonesia to avoid the use of first language transfer and the use of the mother tongue in improving their English writing. The essential grammar is a part of language learning that no one can have to claim against teaching it (Okurkova Klara, 2008). Writing without regard to grammar would be disorganized and causes the problem in communication. The reader will be misunderstanding with the writers' mean. In reducing the readers' misunderstanding, the writers have to understand well about grammar. The basic grammar that has learned to avoid the misunderstanding by the reader is preposition.

A preposition is a small thing to connect one word to another. It is simple but not all the students correctly used it. Preposition are words that consist of at, in, on, near, with, without that uses noun phrases providing information about time (at nine o'clock, in the evening), place (on the chair, at home) and other connections (with a spoon, without you) involving actions and things (Yule, 2010). It is a tool to organize the sentence become meaningful. A preposition is words that connect one sentence to another, it shows that both sentences are interconnected (Seaton \& Mew, 2007). Error in a preposition is due to incomplete learning of the rules. The different parts of speech in sentences could fluster the learners and let them make the prepositional error such as omission, addition, or selection of the wrong preposition in English (Murshidi, 2014).

The error prepositions in students' English writing are influenced by some factors. There are two reasons of errors; first is inter-language errors that used by learners of L1 or mother tongue and second is intra-lingual and developmental errors that used by learners' ability at specific phase and demonstrate certain of the general characteristics of language acquisition (Richards, 1971). Another researcher states that there are four types of errors in writing preposition; omissions, additions, misformation, and misordering (Dulay, Burt, \& Kransen, 1982). Based on the problems above, it means that the students do not master the English grammar well.

Dealing with the explanation above, this research elaborates the analyzing what are the kinds of errors preposition that produces by students of the first semester of English Education Department at Unisla and the types of errors are mostly produced in students' writing. The research was done in 2019. Hence, this research was done to identify and 
analyze the kinds of errors that are mostly produced by the students of the first semester of English Education Department at Unisla.

\section{RESEARCH METHOD \\ Research Design}

This research attempt to analyzing the kinds of errors preposition in students' writing English and most of the errors preposition that produced by students in their writing. The researcher conducted a descriptive qualitative method. It was related to qualitative research. The qualitative method helps the researcher to understand more about people, social, and cultural phenomena in around their live (Dörnyei \& Griffee, 2010).

The source of data is students' writing assignment. The data obtained from students' writing assignments. The researcher classified the students' error based on Dulay, et al (21982), she calculated the percentages of error that found in students' writing assignment, and then she interpreted the data descriptively.

\section{Subject of Research}

The subject of this study is the students' first semester of English Education Department at Universitas Islam Lamongan in the academic 2019/2020. English Education Department has two classes in the first semester. A class consists of 23 students and B class consists of 22 students. The total of students are 45 students, it means that there are 45 students' writing assignments which analyzed. The researcher uses students' writing procedure text to be analyzed.

\section{Instruments}

The instrument of this research is documentation. Documentation contains text (words), images, or tables that recorded without researcher's interference (Bowen, 2009). The main instruments of this research were the researcher herself and the partner in her institution. In qualitative research, the researcher is as an instrument (Patton, 2002). The researchers identified the kinds of prepositions in students' writing assignment. After getting the data from identifying, the researcher classified errors preposition into four kinds of errors by using theory suggested by Dulay, et al (1982). Then, the researchers identified the most errors preposition in students' writing.

\section{Data Analysis}

Qualitative research is a method which conveyed in descriptive analysis to describe and to interpret the result of qualitative data. In conducting this study, it needs some procedures. It is elaborated like;

Firstly, to collect the data writer give the students an assignment. The writer does not limit the topic of the students' writing assignments. The students' writing assignment analyzed by classifying the errors in preposition based on four types of preposition errors. Then the writer classified the error on the table in her notes. The table shows the kinds of prepositional error are produced and the types of error are produced.

Table 1

Students' Error in Writing

\begin{tabular}{|c|c|c|c|c|}
\hline \multirow{2}{*}{ No } & \multicolumn{4}{|c|}{ Kind of Error } \\
\cline { 2 - 5 } & Omission & Additin & Misformation & Misordering \\
\hline 1 & & & & \\
\hline 2 & & & & \\
\hline 3 & & & & \\
\hline 4 & & & & \\
\hline 5 & & & & \\
\hline
\end{tabular}


Second, the writer accumulates the percentages of the most errors are produced by students in writing preposition. The writer counts the frequency and percentages of each error. It put it on the writer's notes. The accumulation of percentages of error analysis in a preposition is to know the most error types produced by students. The percentages of are count by the following formula:

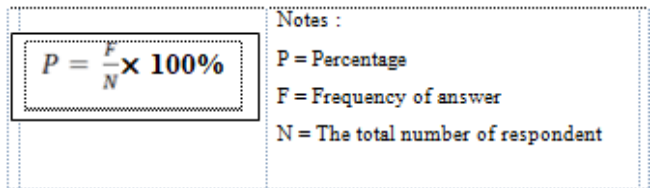

Figure 1. Formula of Percentages

Third, after analyzing and classifying the students' errors in writing prepositions, the writer interpreted all of the data descriptively. Then the writer concluded the study.

Second, the writer accumulates the percentages of the most errors are produced by students in writing preposition. The writer counts the frequency and percentages of each error. It put it on the writer's notes. The accumulation of percentages of error analysis in preposition is in order to know the most error types produced by students.

\section{RESEARCH FINDINGS AND DISCUSSION Research Findings}

\section{Kind of Errors in Prepositional}

There are four errors in the preposition (Dulay, Burt, \& Kransen, 1982). This study has been analyzed the students' errors based on his theory. Students' writing assignment has been analyzed by the writer to know the kind of errors produced in the student's writing. It grouped incorrect sentences into each type of errors. Those kinds of incorrect use of prepositions are counted to know the percentage and to identify the most errors are produced. It describes below.

\section{a. Omission}

Dulay et al (1982) state that sentence called error when there is an absence of an item that must not appear in a well-formed utterance. Here, some students made omission since they did not know there were components or certain other words that must appear in their sentences. Most errors were made in using prepositions or linking verb. The lists of omissions' errors are presented in table 2.

Table 2

Omission Errors

\begin{tabular}{|c|c|c|}
\hline No & Errors' Sentences & Correction \\
\hline 1 & $\begin{array}{l}\text { After I arrived her house, I put my } \\
\text { motorcycle }\end{array}$ & $\begin{array}{l}\text { After arrived at her house, I put my } \\
\text { motorcycle }\end{array}$ \\
\hline 2 & We want play at home & I want to play at home \\
\hline "3." & "Every aftemoon we decided to go home & In the aftemoon we decided to go home \\
\hline 4 & I must be waitmg 3 hours & I must be waitmg for 3 hours \\
\hline 5 & I prepared go to my sister's house & I prepared to go to my sister s house \\
\hline 6 & We visit Parangtritis beach & We visit to Parangtritis beach \\
\hline 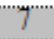 & I played together by my teacher & I played together with my teacher \\
\hline 8 & l arrived in my home on $9 \mathrm{pm}$ & l arrved in my home at $9 \mathrm{pm}$ \\
\hline " & I went the market buy fruits & I went to the market to buy fruits \\
\hline 10 & We arrived joga in the moming & We arrived at jogja in the moming \\
\hline 11 & It try applied the factory & I try to apply the factory \\
\hline 12 & I was just home alone & I was just at home alone \\
\hline 13 & I always dreamed being famous & I always dreamed of being famous \\
\hline 14 & I' was school in SMPN1 Lamongan & I was school at SMPN1 Lamongan \\
\hline
\end{tabular}

Considering the table above, the researcher describes the sentences based on the kind of omission preposition used by students of the first semester. 
First, the sentence "After I arrived her house, I put my motorcycle". This sentence is wrong. The correct preposition before "her house" is "at". The use of "at" should appear in that sentence because it shows the place. According to Collins (1991), preposition is applied in several situations such as when something happens at a particular time; if we are at a place and being there; and if we point at something. We use "at" to show a point or particular location or smaller places. It means "her house" is a particular location. So the correct sentence is "After I arrived at her house, I put my motorcycle". There are similar error sentences in using "at". It shows on the table 4.1 numbers, 6, 10, 12, and 14. Number 8 is used the preposition "at" at specific times. The sentence "I arrived in my home on 9 p.m". "On" should change with "at" because "9 p.m" is a specific time. So, the sentence is "I arrived in my home at 9 p.m"

Second, the sentence "We want play at home" is also wrong because there is an absence of item that should be present in that sentence. The correct one is "We want to play at home". It caused there two verbs in that sentence "want" and "play" so the second verb must be followed by "to". It also happened on number 5 and 11.

Third, "Every afternoon we decided to go home" the third error in this omission. The error omission is in using the preposition of time. The correct sentence is "In the afternoon we decided to go home". The preposition "in" is used with specific time expressions referring to the morning, afternoon, or evening.

Fourth, the sentence "I must be waiting 3 hours". There is an absence preposition in this sentence, it is "for". The preposition "for" is used to show time duration or period. So the correct sentence is "I must be waiting for 3 hours".

Fifth, the sentence "I went in market in buying some fruits" is omission preposition. The preposition "to" is needed to show a direction. So the correct sentence is "I went to market to buy some fruits". The similar error based on table 4.1 is number 6 .

Sixth, the sentence "I played football together by my teacher" is incorrect. The sentence must appear the preposition "with" to show togetherness. So the correct sentence is "I played together with my teacher".

The last sentence is the error of using "of" in a sentence "I always dreamed being famous". The use "of" expresses the relationship of a part of something to its whole. So the correct sentence is "I always dreamed for being famous".

\section{b. Addition}

The second type of preposition errors is addition errors. It is one of the preposition's errors that characterizes by the presence of an item that must not appear in a well-formed utterance (Dulay, Burt, \& Kransen, 1982). The additions' errors show in the table 3. 
Table 3

Addition Error

\begin{tabular}{|c|c|c|}
\hline No & Error Sentences & Correction \\
\hline 1 & We are arrived in here tonight & We are arrived here tonight \\
\hline 2 & Mr. Isyul told to us about the location & Mr. Isyul told us about the location \\
\hline 3 & $\begin{array}{l}\text { we were having lunch and prayed in } \\
\text { there }\end{array}$ & we were having lunch and prayed there \\
\hline 4 & In there, it's so cool & "There, it's so cool" \\
\hline 5 & $\begin{array}{l}\text { I was happy because the special one is } \\
\text { on there too }\end{array}$ & I was happy because the special is there too \\
\hline 6 & In there, I saw interesting thing & "There, I saw interesting thing \\
\hline 7 & In there, my friends and I felt happy & 'There, my friends and I felt happy' \\
\hline 8 & We brought our breakfast to on my car & We brought our breakfast to my car \\
\hline 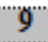 & I went to home & I went home \\
\hline 10 & We enjoyed for the game & We enjoyed the game \\
\hline 11 & We tried a few games in there & "We tried a few games there \\
\hline 12 & My trip stopped in there & My trip stopped there \\
\hline 13 & I enjoy to the sight & I'enjoy the sight \\
\hline 14 & We arrived in there at 90 clock & We arrived there at 90 clock \\
\hline 15 & After we arrived in there & After we arrived there \\
\hline 16 & We enjoyed the scenery in the tea garden & We enjoyed the scenery at the tea garden \\
\hline 17 & We went go home at $06 \mathrm{pm}$ & We went home at $06 \mathrm{pm}$ \\
\hline 18 & $\begin{array}{l}1 \text { went to the kindergarten to teach in } \\
\text { there }\end{array}$ & I went to the kindergarten to teach there \\
\hline 19 & I call for my brother & I call my brother \\
\hline 20 & We waste our time enjoy the scenery & We waste our time to enjoy the scenery \\
\hline 21 & We went to beach to refreshing & We went to the beach for refreshing \\
\hline 22 & We can to see them & We can see them \\
\hline 23 & In there, my friends and I were happy & There, my friends and I were happy \\
\hline
\end{tabular}

Following the table 3, the writer analyzed the sentences based on types of addition. 23 sentences found in the students' first-semester writing. First, the sentence number 1 and 12; "We are arrived in here tonight" and "We tried a few games in there" are not correct. There is an error in using the preposition of place. The preposition "in" have to omit in those sentences. If those sentences using "in", it means incorrect. Those sentences do not need it because it has a double meaning. So the correct sentences are "We are arrived here tonight" and "We tried a few games there". Similar sentences have shown on the table above (See numbers $3,4,5,6,7,13,15,16$, and 24). It also happened in the sentence "I went to the kindergarten to teach in there". It does not need preposition "in" because the word "there" shows adverb of place. So the correct sentence is "I went to the kindergarten to teach there".

Second, the sentence "Mr. Isyul told to us about the location" is incorrect. The verb "told" in this sentence normally followed by a direct object without a preposition. So the correct sentence is "Mr. Isyul told us about the location".

Third, the sentence "We brought our breakfast to on my car" is not correct. This sentence has two prepositions. The preposition "on" must omit because the preposition "to" has shown a direction. So the correct sentence is "We brought our breakfast to my car". The can use "on" in the sentence "We took picture on ship" because "on" express a surface something.

Fourth, the sentence "I went to home" is the fourth of addition error in students' firstsemester writing. The use of "to" in that sentence is wrong, we must omit it. This sentence does not show direction. Here, the word "went home" means "pulang" in Indonesia. So the correct answer is "I went home". The similar sentences based on the table above is number 18. 
Fifth, "We enjoyed for the game" and "I call for my brother" are incorrect sentences. Those sentences do not need the preposition "for" because both sentences have direct objects. The direct objects are "the games" and "my brother". So the correct sentences are "We enjoyed the game" and "I call my brother". It means that those verbs are normally followed by a direct object, so it not used preposition in those sentences. It also happened in the sentence "I enjoy to the sight" is incorrect. The direct object "the sight" does not need a preposition, so the right sentence is "I enjoy the sight". A similar sentence based on the table above is number 22 .

Sixth, the use of "to" in a sentence "We can to see them" does not need it. It is a grammatical error. The use of preposition after modal (can) is incorrect. In the present form, the correct sentence is "modal + verb1", so the correct answer is "We can see them".

\section{c. Misformation}

The third error in a preposition is misformation. Dulay et al (1982) state that misformation error is the incorrect presence of an item in an utterance. There were 31 students' error misinformations in their writing. The misformations' errors show in the table 4.

Table 4.

Misformation Errors

\begin{tabular}{|c|c|c|}
\hline No & Error Sentences & Correction \\
\hline 1 & Different in city, its air is very cold & Different from city, its air is very cold \\
\hline 2 & We are arrived in Lemah A bang Station" & We are arrived at Lemah Abang Station \\
\hline 3 & $\begin{array}{l}\text { We felt up set because my friend failed to' } \\
\text { audition }\end{array}$ & $\begin{array}{l}\text { We felt upset because my friend failed in } \\
\text { audition }\end{array}$ \\
\hline 4 & I must be waiting in my university & I must be waiting at my university \\
\hline 5 & We went to the hotel for stay & We went to the hotel to stay \\
\hline $6 "$ & Although in first 1 was so bored" & Although at first 1 was so bored \\
\hline 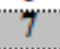 & I got my holiday in my uncle's house & I got my holiday at my uncle's house \\
\hline 8 & $\begin{array}{l}\text { In the sixth grade, I have to go to study } \\
\text { tour }\end{array}$ & At the sixth grade, Thave to go to study tour \\
\hline " & "We played vehicles in Jatim Park' & We played vehicles at Jatim Park \\
\hline 10 & $\begin{array}{l}\text { My friends and } 1 \text { spend our holiday in } \\
\text { Borobudur }\end{array}$ & $\begin{array}{l}\text { My friends and } 1 \text { spend our holiday at } \\
\text { Borobudur }\end{array}$ \\
\hline 11 & My first job is difficult to me & My first job is difficult for me \\
\hline 12 & But I usually tried for understand & "But I usually tried to understand \\
\hline 13 & "In second day, 1 start to learn speak up & At second day, 1 start to learn speak up \\
\hline 14 & I started for study more that first day & I started to study more that first day \\
\hline 15 & "We will swim in the beach" & "We will swim at the beach" \\
\hline 16 & We spent time in villa for a day & We spent time at villa for a day \\
\hline 17 & "We played in park" & We played at park \\
\hline 18 & Idrink coconut ice in beach" & I drink coconut ice at beach" \\
\hline "19" & $\begin{array}{l}\text { We continued the travel and dropped in } \\
\text { the restaurant }\end{array}$ & $\begin{array}{l}\text { We continued the travel and dropped at the } \\
\text { restaurant }\end{array}$ \\
\hline 20 & I am forbidden with my mother & I am forbidden by my mother \\
\hline 21 & My mother forbid me for work & My mother forbid me to work \\
\hline 22 & I instruct my mother go to market & linstruct my mother to go to market \\
\hline 23 & $\begin{array}{l}\text { We devise to dinner in a chickennoodle } \\
\text { shop }\end{array}$ & $\begin{array}{l}\text { We devise for dinner in a chicken noodle } \\
\text { shop }\end{array}$ \\
\hline 24 & We met Dimas Sete shooting on there & We met Dimas Sete shooting there \\
\hline 25 & $\begin{array}{l}\text { We just walk at the street to see the } \\
\text { panorama }\end{array}$ & $\begin{array}{l}\text { We just walk along the street to see the } \\
\text { panorama }\end{array}$ \\
\hline 26 & I put my cellphone in table & 1 put my cellphone on the table \\
\hline 27 & $\begin{array}{l}\text { Iremember whenl was in first grade of } \\
\text { Junior high school }\end{array}$ & $\begin{array}{l}\text { Iremember whenl was at first grade of } \\
\text { Junior high school }\end{array}$ \\
\hline 28 & "He come in my school" & "He comes to my school" \\
\hline 29 & "He still teach in my school" & "Hestill teaches at my school" \\
\hline 30 & We around the university by foot & "We around the university on foot" \\
\hline "31'" & We took picture in ship & We took picture on ship \\
\hline
\end{tabular}


Considering the table 4, the writer took some samples to analyze and it describes below. First, the sentence "Different in city, its air is very cold" is an incorrect sentence. The words "different in" must be replaced "different from" because the sentence compares two objects, they are city and village. So the correct sentence is "Different from city, its air is very cold".

Second, the sentence "We felt upset because my friend failed to audition" is incorrect. The writer must uses preposition "in" to express the caused or the purpose of something we have done. Based on the sentence, the writer's friend had an audition and he failed. So the correct sentence is "We felt upset because my friend failed in audition".

Third, the sentence "My first job is difficult to me" is not correct. The preposition "to" follows a verb, like work, study, understand, and others. The word "me" is not a verb, it is a person. So it can replace by "for" because it can follow by non-verb, like noun or pronoun. The sentence should be "My first job is difficult for me". The similar incorrect sentences based on the table above are numbers 5,12, 14, 21, and 23.

Fourth, the sentence "In the sixth grade, I have to go to study tour" is not correct. An error preposition found "in" instead "at". Here, "in" shows the grade, so it has to replace "at". So the correct sentence is "at the sixth grade, I have to go to study tour". The use "at" has been described above. The similar incorrect sentences based on the table above are numbers $2,4,6,7,9,10,13,15,16,17,18,19,27$, and 29. Sometime the use of "at" to explain the specific place is not correct because however, we use the preposition based on the function of a sentence. Such as "We just walk at the street to see the panorama" is not correct. It has to replace "along". The preposition "along" describes that the people have a meaning moving on to other places. So the correct answer is "We just walk along the street to see the panorama".

Fifth, "We around the university by foot" is incorrect. The word "foot" in this sentence is not an instrument that they use to around the university, but it is the manner how they rounded the university. It must be replaced by "on foot". So the correct sentence is "We around the university on foot".

Sixth, "I am forbidden with my mother" is not a correct sentence. The use "with" is an error of misformation. It has to replace by "by" because it is a passive voice. In this case, it is a preposition of agents that used for a thing. It is caused by another thing in a sentence. So the correct sentence is "I am forbidden by my mother".

The last is the differences between using the preposition "in" and "on". "In" is used to talk about a situation in which something is enclosed by something else. On the other hand, "on" is used to talk about the situation when the object is placed above or outside something else. "In" used to showing time such as month, years, season, decades and century, whereas "on" followed by day, date, and special occasion. The sentence "I put my cellphone in table" is wrong. It has to replace "on" because "On" represents something is placed above something and is in tough with it. So the correct sentence is "I put my cellphone on table". The similar sentence is on number 31 .

\section{d. Misordering}

The last type of preposition errors is Misordering. It is characterized by incorrect placement of morpheme or a group of morpheme in an utterance (Dulay, Burt, \& Kransen, 1982). Based on the analysis of students' first-semester writing, there is an incorrect sentence. It shows in table 5. 
Table 5

Misordering Error

\begin{tabular}{|c|l|c|}
\hline No & \multicolumn{1}{|c|}{ Error Sentences } & Correction \\
\hline 1 & $\begin{array}{l}\text { We leave from house about at } 7 \\
\text { o'clock }\end{array}$ & We leave from house at about 7 'clock \\
\hline
\end{tabular}

Based on the table 5, it can see that sentence is incorrect. The correct one is "at about" because the preposition "at" shows the time of the clock and "about" is used to indicate approximate time. So, this sentence has incorrect placement of an item. The correct sentence is "We leave from house at about 7 o'clock".

\section{The Most Types of Prepositional Error}

The most errors were made by the students is misinformation. It caused that they are less familiar with English structure. It was supported by a statement of Muhammad Fajri et al (2017), the cause of learners making misinformation was they did really not comprehend yet about the transformation of particular words. Considering the data and explanation above, the researcher counted the percentage of each preposition errors in writing that produced by the students' first semester of English Education Department at Unisla. The total percentage of errors show in the following table 6.

Table 6

Percentage of Preposition Errors

\begin{tabular}{|c|c|c|c|}
\hline No & Types of Errors & Number of Errors & Percentages \\
\hline 1 & Omission Errors & 14 & $20,29 \%$ \\
\hline 2 & Addition Errors & 23 & $33,33 \%$ \\
\hline 3 & Xisformation Errors & 31 & $44,93 \%$ \\
\hline 4 & Alsordering Errors & 1 & $1,45 \%$ \\
\hline & & 69 & $100 \%$ \\
\hline
\end{tabular}

The table 6 shows that the students who produced omission errors are 20,29\%, 33,33\% of students' writing are additions' errors, 44,93\% of students' writing are misformations' errors, and $1,45 \%$ of students' writing are errors in misordering. So the most types of prepositional error that produced in writing by the students' first-semester of English Education Department at Unisla is misformation errors.

\section{Discussion}

Based on the finding above, first, there were 14 omission errors. It means that there was 20,29 percent of omission errors in students' writing preposition. The result showed that there was an absence of an item that must not appear in a well-formed utterance. Second, there were 23 additional errors. It means that there was 33,33 percent of additional errors in students' writing prepositions. Based on the result of analyzing, there was an item that must not appear in a well-formed utterance in the students' writing. Third, the error found in analyzing students' writing is misformation errors. The students' writing can be said misformation error due to the incorrect presence of an item in an utterance. There were 31 misformation errors. It means 44,93 percent of students' error in writing preposition was misformation. The last was the misordering error. It called misordering error due to incorrect placement of morpheme or a group of morpheme in an utterance in students' writing. There was only 1 student who is incorrect placement of morpheme or a group of morpheme in an utterance. The percentage of it was 1,45 percent. So, considering the finding, identifying the types of error that were mostly produced was misformation error. It caused that students are not familiar with English structure and also they did not comprehend yet about the transformation of particular words, especially in English. 


\section{CONCLUSION}

As known on the discussion above, most of the students' writing found preposition errors. It means although the students have a high grade of education, they still make some errors in writing prepositions. It has been shown at finding the result of this study. Between four types of errors; omission, addition, misinformation, and misordering, mostly, they made error in misinformation. So that way, they have to learn more about grammar, especially in a preposition, so that no more errors are found in writing preposition and they have to understand well about the importance of learning grammar to support their writing in English. The lectures must have some creative techniques or methods or media or approaches in teaching grammar to the students to understand well about each kind of grammar that they have learned. So, they can implement it to write and speak in English correctly.

\section{REFERENCES}

Abdillah, Muhammad F., et al. (2017). An Analysis Of Grammatical Errors In Learners' Descriptive Writings At SMA Al-kautsar Bandar Lampung. UNILA Journal of English Teaching, 6(9), 1-13. $\quad$ Retrieved from https://www.neliti.com/id/publications/213717/an-analysis-of-grammatical-errors-inlearners-descriptive-writings-at-sma-al-kau.

Anjayani, P., Suprapto, D., \& Hum, M. (2016). Error Analysis on the Use of Prepositions in Students 'Writing ( A Case Study of the Eleventh Grade Students of SMA Negeri 9 Semarang in the. Journal, 5(2), 1-6. Retrieved from https://journal.unnes.ac.id/sju/index.php/elt/article/view/11227.

Bowen, G. A. (2009). Document analysis as a qualitative research method. Qualitative Research Journal, 9(2), 27-40. https://doi.org/10.3316/QRJ0902027.

Brown, H. D. (2007). Principles of Language Learning And Teaching (Fifth Edition). New York: Pearson Education, Inc.

Collins. (1991). Collins Cobuild English Guides: Preposition. London: Harper Collins Publisher.

Dörnyei, Z., \& Griffee, D. T. (2010). Research Methods in Applied Linguistics. TESOL Journal, 1(1), 181-183. https://doi.org/10.5054/tj.2010.215611.

Dulay, H., Burt, M., \& Kransen, S. (1982). Language Two (Vol. 67). New York: Oxford University Press, Inc.

Murshidi, G. Al. (2014). the Difficulties of Uae University Students in the Use of Preposition. 10(17), 173-191.

Napitupulu, S. (2017). Analyzing Linguistic Errors in Writing an English Letter: A Case Study of Indonesian Undergraduate Students. International Journal of Language and Linguistics, 5(3), 71. https://doi.org/10.11648/j.ijl1.20170503.12.

Okurkova Klara. (2008). A Grammar Practice Book for Adult Beginner Learners of English.

Patton, M. (2002). Qualitative research and evaluation methods (3rd ed.). Newbury Park, CA: Sage.

Richards, J. C. (1971). A non-contrastive approach to error analysis. ELT Journal, 25(3), 204-219. https://doi.org/10.1093/elt/XXV.3.204.

Seaton, A., \& Mew, Y. H. (2007). Basic English. In English Studies (1st ed.). https://doi.org/10.1080/00138384608596774.

Suzanne, N. (2017). An Aanalysis of Preposition Errors: The Case of in, on, and at. Lingua Didaktika: Jurnal Bahasa Dan Pembelajaran Bahasa, 11(1), 13. https://doi.org/10.24036/ld.v11i1.7408.

Yule, G. (2010). The Study of Language (Fourth Edition). New York: Cambridge University Press. 